Hansen, K. H. (2017). Hva er yrkesdidaktikk i dagens yrkesopplæring i skole. Scandinavian Journal of vocations in Development.

Http://dx.doi.org/10.7577/sjvd.2134

Fagfellevurdert artikkel

(peer reviewed article)

\title{
Hva er yrkesdidaktikk i dagens yrkesopplæring i skole?
}

Forfatter:

Kari Henriette Hansen

Førstelektor,

Norges Teknisk - naturvitenskapelige universitet - NTNU,

Institutt for lærerutdanning. 7491 Trondheim

kari.hansen@ntnu.no

Nøkkelord: Yrkesdidaktikk, praksisbasert, yrkes- og interessedifferensiert, demokrati og mening 


\section{Sammendrag:}

I dag forventes det at yrkesfaglæreren kan tilrettelegge og lede opplæring mot mange og ulike yrker og fagbrevområder som elevene utdanner seg til i en og samme klasse. Forskning og evaluering etter Kunnskapsløftet KL (06) viser store didaktiske utfordringer i dagens yrkesopplæring, både første året i videregående kurs 1 (Vg1) og i flere av de brede videregående kurs 2 (Vg2). Det er derfor et behov for å diskutere hva som skal til for å utvikle en relevant og fremtidsrettet yrkesopplæring for alle elevene i skolen. De brede utdanningsprogrammene har ført til at mange elever i Vg1 må gjennomgå moduler av utvalgte yrker, selv om de har bestemt seg for et yrke når de begynner i videregående. I Vg2 risikerer elever å komme opp til eksamen i et annet yrke enn det de har fått lærlingplass i.

Formålet med artikkelen er å diskutere hva yrkesdidaktikken bør inneholde for å være et nyttig redskap i utvikling av yrkeskompetanse og relevans, demokrati og elevmedvirkning i yrkesopplæringen.

Grunnlaget for denne artikkelen, baserer seg på funn fra et treårig FoU-samarbeid med et tverrfaglig lærerteam innen bygg- og anleggsteknikk. Metodene som brukes i studien er elektronisk spørreunders $\varnothing$ kelse blant elever og gruppeintervju med yrkesfaglærere.

Funnene fra forskningsarbeidet viser at innholdet i yrkesdidaktikken bør endres for å sikre kvalitet i yrkesopplæringens $\mathrm{Vg} 1$ og brede $\mathrm{Vg}$ 2, og for å sikre relevans i

yrkesfaglærerutdanningene.

Nøkkelord: Yrkesdidaktikk, praksisbasert, yrkes- og interessedifferensiert, demokrati og mening 


\begin{abstract}
:
Today, vocational teachers are expected to organize and adapt their training to classes where the students are trained in many different occupations and certificate areas. Research and evaluations of the curriculum in the Knowledge Promotion KL (06) show that there are considerable didactical challenges in contemporary vocational training, both in the first year in high school courses ( $\mathrm{Vg} 1)$ and in several of the broader courses in the second year $(\mathrm{Vg} 2)$. Consequently, there is a need to discuss what it takes to develop relevant and future-oriented vocational training for all students in upper secondary school. The broad educational program approach entails that many students in Vg1 must go through a selection of modules featuring possible future professions, although they have already decided their profession when they move on to $\mathrm{Vg}$ 2. In $\mathrm{Vg}$ 2, student risk being selected for a final exam in a profession that is different from the one they are an apprentice in.

The purpose of the article is to discuss what vocational didactics should include to become a useful tool for development of vocational competence and relevance, democracy and student participation in vocational education and training.

This article`s empirical data is based on findings from a three-year research collaboration with a multidisciplinary team of teachers in building and construction. The methods used in this study are electronic survey among students and group interview with vocational teachers. The result of this research shows that vocational didactics needs to be renewed to ensure quality in vocational education, and to ensure relevance in the vocational teacher educations.
\end{abstract}

Keywords:

Vocational didactics, practical based, differentiated based on vocations and interests, democracy, meaningful 


\section{Innledning}

Yrkesdidaktikk handler om hvordan man lærer å utøve og forstå yrker og yrkesfaglige arbeidsprosesser. Yrkesdidaktikk er derfor et sentralt verktøy for lærere ved yrkesfaglige utdanningsprogrammer og utgjør en viktig del av yrkesfaglærerutdanningene. Med innføringen av Reform 94 ble det innført brede studieretninger innenfor yrkesutdanningen i videregående opplæring. Brede betyr her at det rekrutteres til mange ulike yrker i hvert av de ulike utdanningsprogrammene. Etter innføringen av Kunnskapsløftet i 2006 KL (06) ble enda flere yrkesfag samlet i hvert av de yrkesfaglige utdanningsprogrammene. Min motivasjon for å skrive artikkelen er behovet for å belyse utfordringer for yrkesdidaktikken i dagens yrkesutdanning i skolen, med tanke på å videreutvikle og endre denne. Det har skjedd store endringer i yrkesopplæringen i skolen siden yrkesdidaktikk ble lansert som begrep for første gang i 1997 (Hiim \& Hippe, 1999). I tilsettingsforskriften er det ingen entydige krav til studiepoeng i yrkesdidaktikk for yrkesfaglærere, og det diskuteres fortsatt blant skoleledere og skoleeiere hvilken yrkesdidaktisk og yrkesfaglig kompetanse en yrkesfaglærer bør inneha. Innledningsvis er det greit å minne om noen sentrale nasjonale føringer for yrkesopplæring i Norge som er relevant for denne diskusjonen. Et uttrykt mål i fag- og yrkesopplæringen er å utdanne gode kvalifiserte fagfolk i tråd med samfunnets behov for kompetanse (Meld. St. 18 (2012-2013). Skolen skal «både svare på arbeidslivets kortsiktige behov, tilpasse opplæringen til elevenes læreforutsetninger og legge til rette for at elevene skal utvikle en kompetanse som kan videreutvikles gjennom flere tiår i et arbeidsliv i endring» (Meld. St. 20 (2012-2013) s. 13). I tillegg gjelder opplæringslovas $§ 1-1$ all grunnopplæring. Her fremheves det at grunnopplæringens overordna formål er utvikling av danning, eller «gagns mennesker».

Elevene skal deriblant utvikle kompetanse i å delta i demokratiske felleskap, lære å arbeide på en samfunnstjenlig måte, lære å tenke kritisk og å handle etisk og miljøbevisst (Opplæringslova 1998).

I Stortingsmelding nr. 30 (2003 - 2004) presiseres det at det bør være en tydelig sammenheng mellom nivåene i fag- og yrkesopplæringen; mellom Vg1, Vg2 og Vg3/opplæring i bedrift. Det skal være helhet og sammenheng mellom programfag (PF), fellesfag (FF) og yrkesfaglig fordypning (YFF). Gjennom læreplanverket ble også fellesfagene formelt og juridisk en inkludert del av en helhetlig yrkesopplæring i skolen (Utdanningsdirektoratet, 2015) Visjonen er at disse fagene skal fungere sammen i en naturlig helhet som bidrar til å utvikle dagsaktuell fag- og yrkeskompetanse (Hansen \& Haaland, 2015a). 
Med KL (06) ble det innført prinsipper for opplæringen som slår fast at elevene skal ha innflytelse på eget læringsarbeid på en slik måte at det sikrer opplevelse av mening og relevans. Den enkelte elev har rett til tilpasset opplæring i tråd med egne forutsetninger, interesser, kompetanse og læringsbehov (Utdanningsdirektoratet, 2006). Nyere forskning viser at innen mange utdanningsprogram får elever som begynner i $\mathrm{Vg} 1$, ikke jobbe med selvvalgte yrker og praktiske, tydelige yrkesrelaterte oppgaver. Mange elever må gjennom moduler av utvalgte yrker, selv om de har bestemt seg for yrke når de begynner $\mathrm{i}$ videregående (Dahlback, Hansen, Haaland \& Sylte, 2011). Formålet med denne artikkelen er å drøfte begrepet yrkesdidaktikk som redskap for utvikling av yrkeskompetanse og relevans, demokrati og elevmedvirkning i yrkesopplæringen etter.

Tittelen på FoU-prosjektet, som ligger til grunn for forskningsarbeidet i denne artikkelen, er Praksisnaer laering ved bygg- og anleggsteknikk (2010-2013). Målet med prosjektet var å oppnå en praksisbasert, helhetlig, yrkesrettet og tverrfaglig opplæring med fellesfagene norsk, engelsk og matematikk, de felles programfagene og yrkesfaglig fordypning integrert.

Bakgrunnen for prosjektet var et uttalt behov for å bedre elevenes motivasjon for læring og utvikle et bedre samarbeid mellom programfag- og fellesfaglærerne. Frafall av elever var ved prosjektstart stort. En annen viktig målsetting var å utvikle et tettere samarbeid mellom skolen og det lokale næringslivet innen bygg- og anleggsteknikk for å ivareta elevenes ulike behov for arbeidslivspraksis.

Etter prosjektperioden hadde vi behov for å forstå lærerens motivasjon for tiltakene de satte i verk, deres erfaringer med og elevenes opplevelser av disse tiltakene.

Problemstillingen som denne artikkelen belyser: Hvilket innhold bør yrkesdidaktikken ha og hvilke prinsipper bør legges til grunn for at yrkesdidaktikken skal ivareta en demokratisk, relevant og meningsfull opplaring for den enkelte elev? 


\section{Et historisk blikk på arbeidet som yrkesfaglærer - En yrkesfaglærer ser tilbake}

På begynnelsen av 1980- tallet ble jeg tilsatt i delstilling som yrkesfaglærer i frisørfag på en videregående skole. Hovedjobben min var utøvelse av fagarbeid i en frisørsalong. Jeg hadde mangeårig erfaring som næringsdrivende og med opplæring av lærlinger. På dette tidspunktet hadde jeg ingen formell pedagogisk utdanning, og det var derfor den faglige og erfaringsbaserte kompetansen jeg hadde utviklet gjennom mange år som frisør og leder, jeg støttet meg til når jeg underviste frisørelever i skolens frisørverksted. Det bør nevnes at frem til 1994 begynte en elev som ønsket å utdanne seg som frisør i Frisør grunnkurs, med opplæring i frisørfaget fra første dag. Elevene hadde ulike faglige, personlige og sosiale bakgrunner. Noen elever kom rett fra ungdomsskolen, andre hadde generell studiekompetanse, noen elever var voksne over 20 år som endelig hadde bestemt seg for yrkesvalg. Dette var en heterogen gruppe elever med det til felles at de ønsket å utdanne seg til frisører. Da jeg startet som lærer, etterlyste jeg en plan over hva elevene skulle lære det første året i skolen. Etterhvert fikk jeg et gulnet ark med mange punkter, med overskriftene praksis og teori på hver side av arket. Jeg kan ikke huske at dette arket fikk avgjørende betydning for mitt virke som lærer det første året. Overgangen fra daglig arbeid med kunder i salongen til å organisere undervisning som skulle utvikle fremtidens frisører var spennende, men også overveldende og utfordrende. Jeg hadde en grunnleggende trygghet i at jeg kunne faget og yrket mitt som den viktigste kilden til det didaktiske arbeidet som ble utviklet sammen med elevene underveis det første året som yrkesfaglærer.

Min erfaring er utviklet i en læringstradisjon preget av mesterlæren. I følge Kvale (1993) er det tre hovedtrekk med mesterlæren som er fremtredende. Produksjonsfellesskap, læring og evaluering gjennom praksis, samt fagidentitet og verdier. Mesteren er en som mestrer sitt fag, han/hun representerer fagets tradisjon og legemliggjør fagets autorative viten og verdier. I min undervisning er det stor sannsynlighet for at det skjedde en direkte blodoverføring, hvor jeg som mester tok mine erfaringsbaserte kunnskaper fra frisørsalongen med inn i klasserommet og overførte disse til mine elever. Klasserommet var en frisørsalong med kundemottak, og som mester i verkstedet hadde jeg stor faglig autoritet. I mangel på læreplaner ble analyse av egen yrkesutøvelse grunnlaget for innholdet i min undervisning.

Det første året som yrkesfaglærer ble i stor grad preget av en undervisning i frisørfaglige arbeidsoppgaver gjennom demonstrasjon, instruksjon, rådgiving og med samtaler underveis. Elevene observerte hva og hvordan, for deretter å få prøve selv. Etterhvert ble jeg utfordret til 
å sette ord på yrkesutøvelsen og arbeidsoppgavene. Jeg husker elevenes spørsmål: Hvorfor holder du saksen og kammen som du gjør når du utfører ulike klippeformer, hvorfor er det viktig at vinkelen på kundens hode er sånn eller sånn og ikke sånn? Elevene hadde krav på forklaring - og jeg ble utfordret til å sette ord på både hva, hvordan og hvorfor. Det var store utfordringer det første året som yrkesfaglærer å sette ord på yrkeskunnskapen, ordkle en innforstått erfarings- og fortrolighetskunnskap som var utviklet og internalisert i hele kroppen gjennom mange år som fagarbeider. At ikke all fortrolighetskunnskap hverken kan eller er $\emptyset$ nskelig å settes ord på, er en egen diskusjon som ikke blir berørt videre i denne artikkelen. Å organisere de sammensatte yrkesfaglige arbeidsoppgavene om til læringsoppgaver, til håndterbare deloppgaver for elevene, uten at elevene mistet målet eller oversikten over den helhetlige arbeidsoppgaven eller yrkesutøvelsen, var en annen utfordring. All aktivitet i klasserommet dreide seg om de daglige arbeidsoppgavene som kundemottak og kundekommunikasjon, vask og hodebunnspleie, klipping og forming, farging mm. Jeg kjenner meg igjen i Haga (1994), som hevder at i bildet av fagarbeideren som går inn i opplæringen i skolen, har det vært det praktiske arbeidet, håndgrepene, følelsen med materialet og maskinene, å få inn en praktisk rasjonalitet i arbeidet osv. som har vært det sentrale. Yrkesdidaktikken jeg praktiserte var formet av at elevene hadde samme yrkesmål. I dagens brede utdanningsprogram, hvor elevene i samme klasse utdanner seg til ulike yrker, er de didaktiske utfordringene helt annerledes. Det kreves en annen yrkesdidaktisk kompetanse blant lærerne for å lede en yrkesutdanning som er relevant, interessant og meningsfull for alle elevene i klassen eller gruppen enten de skal utdanne seg til frisør, møbelsnekker eller skredder.

\section{Dagens utfordringer for lærere ved yrkesfaglige utdanningsprogrammer - En skole i endring}

Nyere forskning viser at det er store utfordringer for lærere på yrkesfag knyttet til elevenes opplevelse av mening i yrkesopplæringen, spesielt i Vg1 og brede Vg2. Det er derfor behov for å analysere behovet for yrkesdidaktisk kompetanse for lærere ved yrkesfaglige utdanningsprogrammer og å vurdere innholdet i begrepet yrkesdidaktikk som redskap i en framtidsrettet yrkesopplæring (Dahlback et al., 2011; Dahlback, Hansen, Haaland \& Rokkones, 2014; Hansen og Haaland, 2015a; Hiim, 2013). Samfunnet, yrkene og bransjene er i stadig endring, samtidig som utdanningsprogrammene har blitt stadig bredere. Det gjør utfordringene med å få til en relevant og oppdatert yrkesutdanning store, og stiller andre krav 
til yrkesfaglærernes og fellesfaglærernes kompetanse og lærergjerning. Utfordringene er spesielt knyttet til hvordan yrkesutdanningen de to første årene i skole kan ivareta samfunnets dagsaktuelle og fremtidige behov for kompetanse i elevenes ulike framtidige yrker i en og samme klasse. Med innføringen av Reform 94 ble antall yrkesfaglige utdanninger elevene kunne søke på det første året, redusert fra ca. 112 til 11 studieretninger. Mitt gamle yrke, frisøryrket, ble med et pennestrøk integrert i studieretningen formgivingsfag sammen med mange andre til dels svært ulike yrkesfag. Med KL (06) ble de 11 yrkesfaglige studieretningene ytterligere redusert til 9 utdanningsprogrammer. Frisørfaget ble, sammen med ca. 50 andre yrker, nå en del av Vg1 design og håndverk. Tilbudene ble færre og bredere.

Begrunnelser for den brede inngangen til yrkesutdanningene er flere. Elever som søker yrkesfag, men er usikre på hvilket yrke de vil utdanne seg til, kan utsette valg av utdanning et år eller to. Et flertall av elevene er ifølge Nyen og Tønder usikre på hvilket fag de skal velge når de begynner på videregående og trenger mer kunnskap om de ulike yrkene for å kunne gjøre et bevisst valg (2012). Å utvikle omstillingsevne har også vært fremhevet som et argument for de brede inngangene til yrkesopplæringen.

De få og brede yrkesfaglige utdanningsprogrammene betyr i praksis ikke at det er en selvfølge at dagens yrkesfagelever får begynne på en spesifikk yrkesutdanning det første året, selv om de har utdannings- og yrkesplaner klare (Aarkrog \& Bang, 2013; Dahlback et al., 2011). Nyere forskning og evaluering av KL (06) viser at av mange skoleeiere, skoleledere og lærere blir læreplanene i de brede utdanningsprogrammene tolket slik at elevene skal ha introduksjon i flere yrker, spesielt det første året. Mange elever blir det første året pålagt en «smakebitpedagogikk» hvor de blir introdusert for mange ulike yrker i moduler gjennom hele skoleåret, selv om de i utgangspunktet hadde klare yrkesønsker da de startet i Vg1 (Dahlback et al., 2011; Hiim, 2013). Andre elever blir tilbudt et generelt teoretisk innhold på Vg1 og delvis også Vg2 som skal gi grunnlag for to år med praktisk yrkesopplæring i bedrift (Aarkrog \& Bang, 2013). Det finnes mange eksempler på dette innenfor utdanningsprogrammene Helse og oppvekstfag, Service og samferdsel og elektrofag. Begge disse variantene virker demotiverende på elevene (Dahlback et al., 2011).

En utfordring som er lite debattert eller inkludert i forskning, er hva som skjer med de elevene som har tatt et aktivt yrkesvalg før de begynner i videregående skole, og hvilke konsekvenser det får for disse ungdommene at de ikke får begynne på en utdanning som oppleves direkte 
relevant for yrket de ønsker å utdanne seg til. Denne gruppe ungdommer utgjør mellom 50 og $60 \%$ av de som søker på yrkesfag (Hansen \& Haaland, 2015a). En elektronisk spørreundersøkelse blant $3000 \mathrm{Vg} 1$ og Vg2- elever gjennomført i fire fylker i 2016, viser at hele $60 \%$ av elevene hadde bestemt seg for yrke før de begynner i videregående (BødtkerLund, Hansen, Haaland \& Vagle, under utgivelse). Forskning innenfor det yrkespedagogiske kunnskapsfeltet, spesielt etter innføringen av KL (06), tyder på at yrkesopplæringen i skolen har store utfordringer med «å treffe» både de elevene som har bestemt seg for yrke og de elevene som trenger mer tid før de tar endelig yrkesvalg det første året.

Utdanningsdirektoratet la høsten 2016 ut sine anbefalinger til endringer av de yrkesfaglige utdanningsprogrammene fra og med høsten 2019 (Utdanningsdirektoratet, 2016a). Anbefalingene betyr i hovedsak at de brede inngangene i yrkesopplæringen blir opprettholdt. Noen nye tilbud i Vg1 og Vg2 blir etablert uten at dette endrer dagens struktur grunnleggende sett.

\section{Datagrunnlag}

Det ble valgt en flermetodisk fenomenologisk tilnærming i studien. Fenomenologisk forskning handler om å finne den sentrale underliggende meningen eller essensen $\mathrm{i}$ en opplevd erfaring (Postholm, 2005). Vi hadde behov for å forstå lærerens tanker og motivasjon for de tiltakene de satte i verk, deres erfaringer med og elevenes opplevelser av disse tiltakene.

Et halvstrukturert/semistrukturert gruppeintervju ble gjennomført med fem lærere. På forhånd ble en liste med hovedspørsmål i form av en tematisk guide utviklet, som hjelp til fremdrift underveis i intervjuprosessen (Kvale \& Brinkmann, 2017). En norsklærer, en engelsklærer og tre yrkesfaglærere fra bygg- og anleggsteknikk deltok i intervjuet. Matematikklærer som deltok i prosjektet var forhindret fra å delta i intervjuet. Intervjuet med lærerne ble transkribert. For å ivareta forskningsarbeidets kvalitet og troverdighet sendte vi det transkriberte intervjuet tilbake til lærerne for gjennomlesing, og de fikk elektronisk tilgang til resultatene fra undersøkelsen med elevene.

Elevenes stemmer ble innhentet via en elektronisk spørreundersøkelse. Spørreskjemaet inneholdt både kvantitative og kvalitative spørsmål, spørsmål med svaralternativer og åpne spørsmål som skulle besvares med beskrivende og reflekterende tekst. Det deltok 36 elever fra Vg1 og Vg 2 Bygg- og anleggsteknikk. 
Et vesentlig mål med det treårige FoU-prosjektet var å oppnå en praksisbasert, helhetlig, yrkesrettet og tverrfaglig opplæring med fellesfagene norsk, engelsk og matematikk, de felles programfagene og yrkesfaglig fordypning integrert. Spørsmålene i begge undes $\varnothing$ kelsene dreide seg om innhold som yrkesvalg, yrkesrelevans og yrkesretting, læringsmiljø, medvirkning og demokrati. I tillegg var vi interessert i lærerens erfaringer med det tverrfaglige samarbeidet mellom fellesfag- og programlærerne. Hovedspørsmålene som vi utformet før intervjuet med lærerne, ble også hovedspørsmålene i spørreundersøkelsen med elevene for å sikre validitet og for å gi et helhetlig bilde av lærernes og elevenes erfaringer fra de samme tiltakene i prosjektet.

Analysen av intervjuet med lærerne ble brukt som grunnlag for utvikling av foreløpige kategorier av både kvalitative og kvantitative resultater fra spørrespørreunders $\varnothing$ kelsen med elevene. I arbeidet med åpen koding og kategorisering av intervjuet med lærerne og spørreundersøkelsen med elevene fremsto det etter hvert noen hovedkategorier som igjen ble delt opp i underkategorier (Strauss \& Corbin, 1998). Da vi jobbet med kategoriseringen, fors $\varnothing$ kte vi å beholde blikket på hovedspørsmålene i begge unders $\varnothing$ kelsene, søke etter hovedmønstre i datamaterialet. Underveis i denne prosessen reflekterte vi over sammenhengen mellom kategorier og betydningen av begrepene elevene og lærerne brukte.

I denne artikkelen presenteres funn fra begge undersøkelsene samlet for å få frem helheten i funnene, belyst gjennom både elevenes og lærerens beskrivelser. Forskerkollega Grete Haaland deltok sammen med meg i utformingen av intervjuguiden og spørreunders $\varnothing$ kelsen, og i gjennomføringen av unders $ø$ kelsene. Vi har sammen skrevet en annen artikkel fra denne studien (Hansen \& Haaland, 2015b).

Funnene i forskningsarbeidene ses i lys av mine erfaringer fra yrkesutdanning i videregående skole og i bedrift, erfaringer som fagarbeider i næringslivet og som lærer ved praktiskpedagogisk utdanning for yrkesfag (PPUY) og treårig yrkesfaglærerutdanning (YFL) i en årrekke. 


\section{Yrkesdidaktikk - et tilbakeblikk}

Yrkesdidaktikk er et nytt begrep historisk sett, selv om didaktikk som redskap for å lære yrker selvsagt har vært i bruk i mange år, spesielt gjennom mesterlæra (Nielsen \& Kvale, 1999). Begrepet yrkesdidaktikk ble for første gang tatt i bruk i rammeplanverket for praktiskpedagogisk utdanning i 1997 (Andersen, 2003). Frem til da var det sentrale fagdidaktikk, knyttet til de enkelte skolefagene. I 1997 ble det bestemt at det skulle tilbys yrkesdidaktiske kurs for lærere i de elleve yrkesfaglige studieretningene i videregående opplæring, som ble innført med Reform 94. Yrkesdidaktikk ble i år 2000 for første gang brukt som begrep på en selvstendig del av et studium med 10 vekttall i den treårige yrkesfaglærerutdanningen og praktisk pedagogisk utdanning for yrkesfaglærere.

I den første veiledningen for utarbeiding av rammeplanen for yrkesdidaktikk ble det tatt utgangspunkt i Hiim og Hippe sin definisjon av yrkesdidaktikk. «Yrkesdidaktikk som praktisk-teoretisk planlegging, gjennomføring, vurdering og kritisk analyse av yrkesspesifikke utdanning - undervisnings og læringsprosesser» (1999, s.180). Etter hvert ble «kritisk analyse og bruk av yrkesfunksjoner/yrkesoppgaver som grunnlag for læring» tatt inn i definisjonen (Hiim og Hippe, 1999, s. 180) Denne definisjonen tolker jeg er sammenfallende med Lennart Nilsson sin forståelse av begrepet (2000) som hevder at yrkesdidaktisk kunnskaps- og virksomhetsområde kjennetegnes av samspillet mellom eleven (den lærende), arbeidsoppgaven og det yrkeslærende mennesket.

Fagdidaktikk ble betraktet som det sentrale didaktikkbegrepet hvor skolefaget \} vitenskapsfaget var i sentrum - ikke arbeidsoppgavene. Definisjonene var et svar på ideen om å se yrkesdidaktikk som en underkategori under fagdidaktikken. Ideen om at fagdidaktikk er det sentrale begrepet, gjør seg fortsatt gjeldende ved enkelte utdanningsinstitusjoner, noe jeg velger å ikke ta inn i denne artikkelen. Som eksempel på ulik forståelse av begrepet, vil jeg som en liten kuriositet nevne at jeg måtte gå flere runder for å få endret innhold i stillingsbeskrivelsen fra yrkesfagdidaktikk til yrkesdidaktikk i tilsettingsbrevet mitt ved NTNU i 2009.

Mange definisjoner av yrkesdidaktikk er utviklet siden 1997, og mye vann har rent $i$ havet siden den gang. I forbindelse med sine ph.d.- arbeider videreutviklet Sannerud (2005) og Haaland Sund (2005) nye og vesentlige perspektiver, knyttet til samfunnsforankring og tilpasset opplæring, inn i definisjonen av yrkesdidaktikk: 
"Yrkesdidaktikk omfatter planlegging, gjennomføring og vurdering av strukturerte yrkesspesifikke læringsforløp i skole og bedrift - basert på relevante arbeidsoppgaver, forstått i en organisatorisk og samfunnsmessig sammenheng - og hvor den lærende som subjekt er involvert i hele forløpet"(Sannerud, 2005, s. 211).

"Planlegging, tilrettelegging, gjennomføring, kritisk analyse og vurdering av yrkesspesifikk opplæring, som er forankret i yrkeslivets og samfunnets uttalte, erfarte og dagsaktuelle behov for kompetanse og den enkelte elevs læringsbehov" (Haaland Sund, 2005, s. 23).

I prosjektet «Yrkesdidaktisk kunnskapsutvikling og implementering av nye læreplaner» (KIP) utviklet vi i 2011 denne definisjonen:

"Planlegging, gjennomføring, vurdering og dokumentasjon med begrunnelser av yrkesspesifikk opplæring i skole og bedrift, som er forankret i yrkeslivets og samfunnets dagsaktuelle og fremtidige behov for kompetanse og den enkelte elevs læringsbehov" (Dahlback et al., 2011, s. 32).

I disse tre definisjonene er elevmedvirkning, elevenes læringsbehov og yrkesforankring fremhevet som grunnleggende viktig. Her presiseres det i tillegg til definisjonen som er nevnt først, at læringsoppgavene må ta utgangspunkt i den enkelte elevs laeringsbehov, som innbefatter elevenes utdannings- og yrkesvalg.

Yrkesdidaktikk som begrep skal vise vei og være et redskap for å oppnå en relevant og oppdatert yrkeskompetanse gjennom yrkesutdanningen i skolen. Det har skjedd store endringer i yrkesutdanningen i skolen etter to store skolereformer fra smale utdanningsløp, hvor mesterlæra, med formidling og instruksjon var sentralt i didaktikken, til i dag, hvor elevenes ulike utdanningsmål gjør denne didaktikken ubrukelig (Dahlback et al., 2011). Nye erfaringer, ny forskning og evaluering av Kunnskapsløftet de siste årene kan tyde på at diskursen om hvordan yrkesopplæringen i skolen skal være, bør holdes varm, og jeg vil videre argumentere for videreutvikling av begrepet yrkesdidaktikk. 


\section{Forholdet mellom fagdidaktikk og yrkesdidaktikk}

Forholdet og forskjellen mellom fagdidaktikk og yrkesdidaktikk kan forenklet illustreres på denne måten (Haaland, 2010):
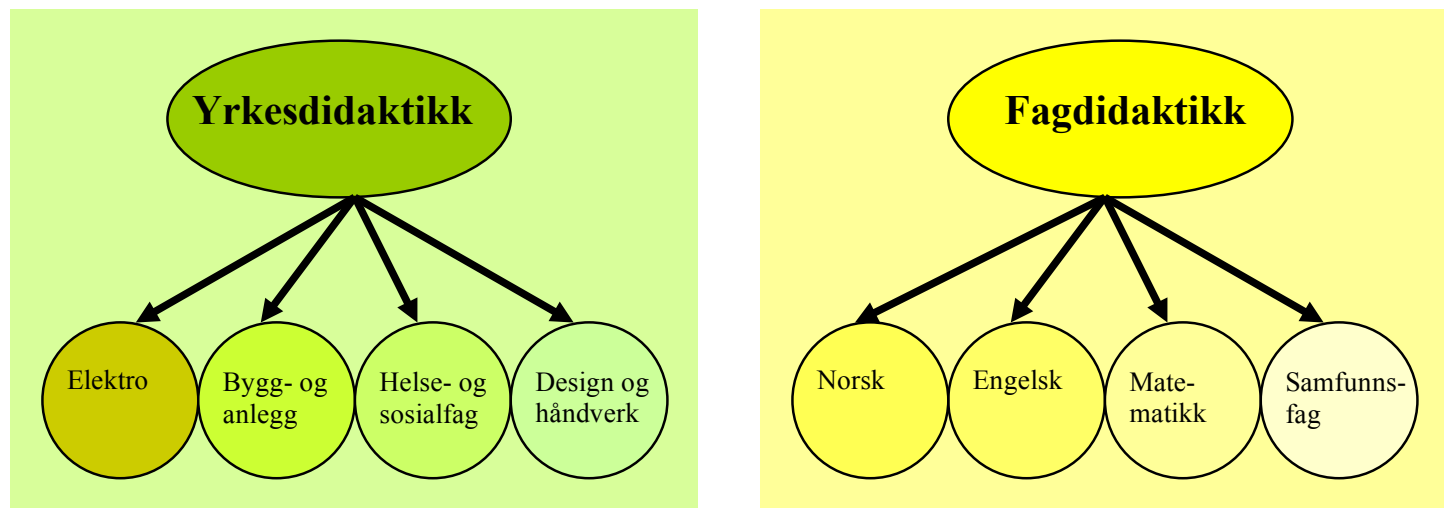

Figur 1 Yrkesdidaktikk og fagdidaktikk

Yrkesdidaktikk handler om hvordan man lærer og underviser i et spesifikt yrke. Som fagarbeider kreves integrerte kunnskaper, ferdigheter og generell kompetanse innen flere skolefag. I en yrkesdidaktisk tilnærming til undervisning og læring, er det dagsaktuelle yrkesoppgaver knyttet til et spesifikt yrke som er utgangspunktet for opplæringen. Det vil si at yrkets behov for kompetanse ligger til grunn for tolkning av læreplaner i de forskjellige skolefagene, valg av arbeidsmåter, utarbeiding av undervisningsmateriell og arbeidsoppgaver og i vurdering av elevenes kompetanse (Dahlback et al., 2011).

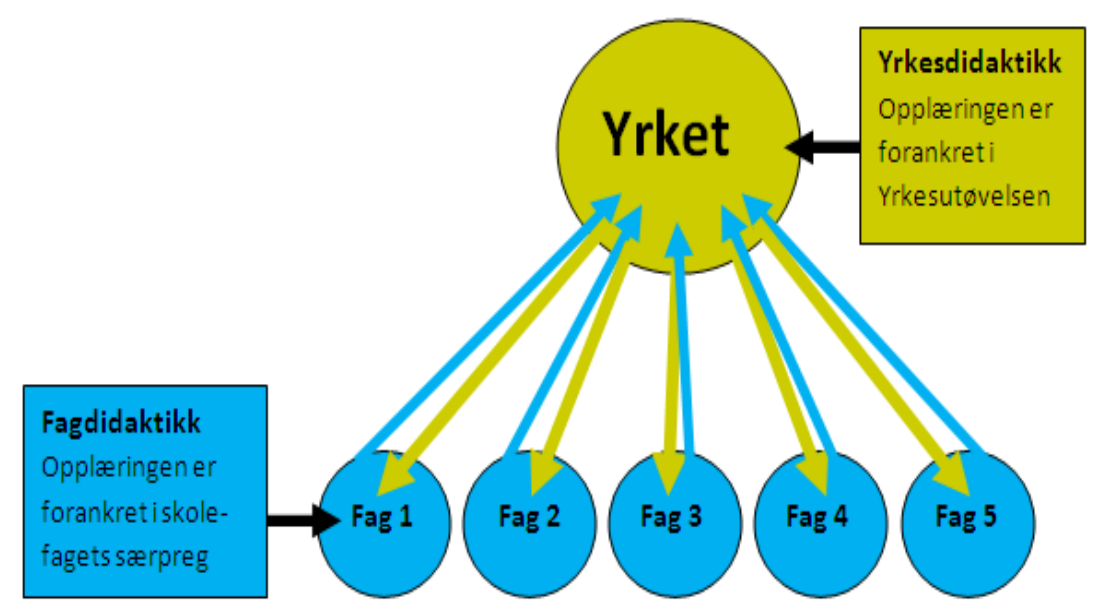

Figur 2 Yrkedidaktisk opplæring er forankret i yrkets behov for kompetanse, mens fagdidaktisk opplæring er forankret i skolefagets særpreg og tradisjon (Dahlback et al., 2011) 
Yrkesdidaktikk er verken et fag eller summen av mange fag. Yrkesutøvelsen er tverrfaglig i sin natur og bør i større grad ha fokus på yrkesoppgaver og derfor også på integrering av skolefagene i elevenes læringsarbeider. For yrkesfaglærere er det krav om 30 studiepoeng yrkesdidaktikk innen det aktuelle utdanningsprogrammet, som for eksempel helse- og oppvekstfag, elektrofag eller design og håndverk, for å bli formelt godkjent som yrkesfaglærer. Yrkesdidaktikk er et overordnet begrep for ulike yrkesdidaktikker; som for eksempel yrkesdidaktikk for elektrofag og yrkesdidaktikk for restaurant- og matfag. Kort fortalt handler yrkesdidaktikken om hvordan man kan lære et spesifikt yrke gjennom å integrere kunnskap og ferdigheter fra flere skolefag og kunnskapsområder.

\section{Resultat}

I denne delen av artikkelen vil jeg drøfte noen sentrale utfordringer og muligheter som har utkrystallisert seg i yrkesutdanning i skole etter snart 10 år med Kunnskapsløftet og som bør ha betydning for innholdet $\mathrm{i}$ begrepet yrkesdidaktikk. Basert på resultater fra denne studien og annen aktuell forskning presenteres også forslag til hvilke yrkesdidaktiske prinsipper som vi fortsatt må ta vare på,og nye prinsipper som bør ivaretas inn i fremtidens yrkesdidaktikkbegrep.

\section{Yrkenes dagsaktuelle arbeidsoppgaver som utgangspunkt for læring i yrkesfagene}

Samspillet mellom yrkenes arbeidsoppgaver og det yrkeslærende mennesket har vært, og bør fortsatt være, et sentralt fundament i yrkesdidaktikken. I følge Hiim og Hippe (1999) handler et viktig yrkesdidaktisk prinsipp om å la praktiske, tydelige yrkesrelaterte oppgaver være sentrum for elevenes læring. Dette er et vesentlig prinsipp både for motivasjon og læring for de elevene som har klare yrkesønsker, og som grunnlag for yrkesvalg for de elevene som trenger ekstra hjelp og støtte til å gjøre dette valget. Dette prinsippet ble også lagt til grunn i det treårige prosjektet. Resultater fra spørreundersøkelsen viste at elevene hadde til dels store forventninger til opplæringen når de søkte seg til bygg- og anleggsteknikk (BA). Nesten halvparten av elevene beskriver forventninger om mer praktisk utdanning, og å lære noe nytt. Over halvparten av elevene hadde bestemt seg for hvilket yrke de ønsket å utdanne seg til før de begynte i Vg1/BA, og de forventet en opplæring som var direkte knyttet til deres yrkesvalg. I gruppeintervjuet understreker yrkesfag- og fellesfaglærere at det blir lagt stor vekt på elevenes yrkesønsker og yrkesdrømmer fra første skoledag i Vg1, og at de selv må få velge arbeidsoppgaver (Hansen \& Haaland, 2015b). 
Tenker at hvis noen lærere påstår at alle elevene som begynner på bygg- og anleggsteknikk(BA) ikke har peiling hva de vil utdanne seg til, da blir jeg skeptisk, da mistenker jeg de lærerne at de ikke har snakket med elevene sine, hvordan er kommunikasjonen og dialogen med elevene da? Det at elevene føler seg hørt, og blir inkludert i de valgene som blir tatt, er veldig grunnleggende (Lærer, BA) i (Hansen og Haaland, 2015b)

Dette vurderer de i sammenheng med elevenes mulighet til å få arbeide med realistiske arbeidsoppgaver og eksempelsituasjoner og på den måten utvikle begynnende forståelse for hva de sentrale oppgavene i yrket dreier seg om (Hiim, 2013). Lærerne mener også det er viktig for elevenes motivasjon at det jobbes med virkelige arbeidsoppdrag.

Vi jobber med reelle arbeidsoppgaver. Minst mulig av det vi bygger på skolen slår vi sund og kaster, hvis vi har en betongjobb, så venter vi til vi får et oppdrag der vi drar ut og støyper ei plate eller bankett til garasje eller lignende. Vi bygger mur for at det skal være noe oppå etterpå! (.....). Da er det viktig å jobbe med noe av verdi, med reelle oppgaver, det er en oppdragsgiver, det er noen som skal ha produktet etterpå. (Lærer, BA) i (Hansen \& Haaland, 2015b).

Funnene i denne studien viser at forventninger om mestring av arbeidsoppgaver er en viktig kilde til motivasjon og innsats. Aarkrog \& Bang (2013) diskuterer utfordringer med de brede utdanningsprogrammene hvor elevene må arbeide med mange ulike yrkesmoduler uavhengig av deres yrkesinteresser. Aarkrog \& Bang fremhever betydningen av at yrkesrelevant praksis i spesifikke yrker kan være et viktig pedagogisk verktøy for bedre å ivareta motivasjon for læring.

I diskussionen af vægtningen af det generelle henholdsvis det specifikke indhold er det vigtigt at overveje, på den ene side hvilke kompetencer den bedst uddannede faglærte arbejdskraft skal have, og på den anden side hvilken pædagogik der bedst udvikler disse kompetencer. Medens vægtningen af et generelt indhold på Vg1 og Vg2 kan tænkes at give eleven den bedste kompetenceplatform, kan den tætte relatering til specifikke yrker være et væsentligt pædagogisk værktøj, der motiverer eleverne for at lære og understøtter deres læringsproces. (2013, s.19).

Dette betyr at jo bredere innganger og jo mer generelt innholdet i læreplanene og yrkesutdanningen er, jo viktigere vil det være å tilrettelegge en praksisrelatert opplæring $\mathrm{i}$ nært samspill med virksomheter og bedrifter. Jeg undres på hvorfor læreplanene tolkes i flere utdanningsprogram slik at elevene det første året skal tilbys en yrkesutdanning i skole preget av et innhold og arbeidsmåter som er generelle og med allmenngyldig karakter? Det bør ikke være slik at elevene må ut i bransjer og virksomheter for å få erfaring med relevante arbeidsoppgaver i selvvalgt(e) yrke(r) det første året i skolen. Slik erfaring bør selvfølgelig legges inn i undervisningen det første året, i kombinasjon med selvvalgt yrkespraksis i 
virksomheter og bedrifter eller i andre videregående skoler med relevant lærerkompetanse. På spørsmålet om hva som har vært spesielt bra dette skoleåret, svarte ca. halvparten av elevene i spørreunders $\varnothing$ kelsen at det praktiske byggearbeidet og de reelle arbeidsoppdragene har vært spesielt bra, både i skolen og i bedriftspraksis. De skiller ikke mellom om de reelle arbeidsoppdragene er organisert via skolen eller bedriften de har vært utplassert i. Det viktige for elevene var å få jobbe med autentiske og relevante arbeidsoppgaver innen bygg- og anleggsteknikk. Et stort flertall av elevene fremhever skolestarten som spesielt bra, hvor de første to - tre ukene uten særlig forkunnskaper startet direkte med bygge faglig produksjon i samarbeid med Vg2 elevene (Hansen \& Haaland, 2015b).

Med KL (06) ble det innført et nytt fag, Prosjekt til fordypning (PTF), som i 2016 endret navn til yrkesfaglig fordypning (YFF). En vesentlig begrunnelse for innføring av PTF var at faget skulle ivareta arbeidslivets behov for faglig spesialisering og slik bidra til å utvikle en kompetanse som er etterspurt i arbeidslivet (Stortingsmelding nr.30, (2003-2004), 2014). I timetall utgjør YF ca. 6 timer pr uke på Vg1 og ca. 9 timer pr uke på Vg2, til sammen et halvt skoleår av de to første årene i videregående skole. Jeg undres om det er sånn at elevene ikke kan forvente at de to første årene i skole er yrkesrelevant, både i programfag og i yrkesfaglig fordyping? Det er i tilfelle en urovekkende argumentasjon at yrkesrelevansen "skal sikres eller settes bort" til bare å gjelde yrkesfaglig fordypning i bedrift og virksomheter. Evaluering av prosjekt til fordypning (PTF) kan tyde på at så er tilfelle det første året i skole (Nyen \& Tønder, 2012). Vi ser utviklingstrekk i yrkesutdanningen i skole der elevene får jobbe med yrkesoppgaver, er det ofte i pålagte yrkesmoduler i en type smakebitspedagogikk. Denne utviklingen bygger på et rasjonalistisk kunnskapssyn hvor disiplinbasert, teoretisk kunnskap, for eksempel matematikk og språk og etter hvert nå også programfagene i yrkesopplæringen, læres på skolen først, for så å anvendes i yrkespraksis og lærlingetid (Hansen \& Haaland, 2015a; Hiim, 2013; Young, 2004). Britt Karin Utvær hevder i sin ph.d.- avhandling at elevenes opplevelse av meningsl $\phi$ shet i programfagene i helse- og oppvekstfag er mer kritisk for hvorvidt de fortsetter i et påbegynt yrkesfaglig utdanningsløp eller ikke (2013) enn opplevelse av meningsløshet i fellesfagene. Det er enkelt å forstå at for de elevene som har bestemt seg for yrke, er det meningsløst å jobbe i pålagte yrkesmoduler som ikke passer til elevenes utdanningsplaner, et helt skoleår! Brede innganger kan selvfølgelig gi rom for $\varnothing \mathrm{kt}$ fleksibilitet for skolene og for de elevene som trenger noe tid til gjøre aktive yrkesvalg. Men med utviklingen av smakebitpedagogikk som grunnlag for innhold og organisering, er det stor fare for at dette går på bekostning av fagligheten i opplæringen og elevenes motivasjon 
(Deichman-Sørensen, Olsen, Skånholt \& Tønder, 2012). I NOU 2015:8, Fremtidens skole blir fagspesifikk kompetanse eller dybdelaring fremhevet som en av de fire kompetanseområder som skal vektlegges i skolens innhold i fremtiden. Å utvikle yrkesidentitet og fagkunnskap innen et yrke som en innforstått erfarings- og fortrolighetskunnskap som internaliseres i hele kroppen, tar mange år. Jeg aner tendenser til at yrkesutdanningen i skolen, der elevene jobber med autentiske selvvalgte yrkesoppgaver og utvikler gryende fortrolighetskunnskap i et yrke, er i ferd med å «forsvinne» i de brede utdanningsprogrammene. Hvis dette er en praksis som etablerer seg, er dette et grunnleggende brudd med yrkesutdanningens historie, tradisjon og læringsprinsipper, men også med nasjonale føringer for yrkesopplæringen.

\section{Arbeidslivspraksis og veksling mellom skole og bedrift det første året}

Det er flere grunner til at fremtidens yrkesdidaktikkbegrep bør inneholde en klar føring om at yrkesfagelevene skal gjennomføre selvvalgt yrkespraksis $i$ bedrift og virksomheter allerede det første året. I løpet av den treårige prosjektperioden utviklet avdelingen ved bygg- og anleggsteknikk et tettere samarbeid med ca. 60 bedrifter, spredt over et større geografisk område. Dette var en viktig målsetting i prosjektet, spesielt innenfor de bransjene og lærefagene der skolenes lærere ikke selv hadde faglig kompetanse. Dette var også viktig for å ivareta elevenes ulike behov for yrkesrelevant praksis fra Vg1. Lærerne hadde kontakt med bedriftene i forkant av elevenes yrkespraksis.

Vi forteller dem at dette er ufaglærte, ferske 16-åringer som ikke har hatt mye opplæring. De mener at dette gjør ingen ting, dette er deres måte å sikre rekruttering på, komme i kontakt med ungdommen på tidlig (Lærer, BA) i (Hansen \& Haaland, 2015b).

Elevene er tydelige i sine svar at de opplever opplæringen i bedrift som motiverende og nyttig. Enkelte elever fremhever at de blir spesielt motivert av «mye praktisk arbeid ute på byggeplass». Et viktig resultat av samarbeidet mellom skolen og bedrifter var at et flertall av Vg2 elevene i undersøkelsen fikk sommerjobb i bedriften de var utplassert i Vg1.

Yrkesrelevant og realistisk arbeidslivspraksis er grunnleggende nødvendig for at elevene skal kunne gjøre sikre valg av yrker og for å utvikle et erfaringsbasert faglig grunnlag i yrker de er interesserte i og ønsker å utdanne seg til (Hiim, 2013). En systematisk veksling mellom yrkesrelevante, tverrfaglige arbeidsoppdrag i skole og praksis i bedrift de to første årene, er utviklet som hovedmodell ved BA- avdelingen hvor vi gjennomførte spørreunders $\varnothing$ kelsen og intervjuet et tverrfaglig lærerteam. Lærerne mente at denne vekslingen hadde bidratt til bedre relevans og sammenheng mellom det som læres i skolen, elevenes yrkesvalg og det som læres 
og praktiseres i bedriftene (Hansen \& Haaland, 2015b). Det å lære et håndverk handler om å øve og utføre håndverket fysisk, men også om å opparbeide evnen til refleksjon og egenvurdering/kritikk for å se potensialet for videreutvikling (Kvale, 1993; Sennet, 2009).

Selv om prosjekt til fordypning ble innført som tiltak for en yrkesbasert utdanning, så viser funn fra FAFO at fagopplæringen i prosjekt til fordypning det første året i stor grad preges av yrkesorientering i skolen istedenfor yrkespraksis i selvvalgte bedrifter og yrker (Nyen \& Tønder, 2012). Det var knyttet store forventninger til at forskriften i yrkesfaglig fordypning (YFF) skulle gi tydelige føringer om yrkespraksis i bedrift da den ble endret fra prosjekt til fordypning til yrkesfaglig fordypning i 2016 (Utdanningsdirektoratet, 2016b). Dette skjedde ikke.

\section{Erfaringslæring både i skole og bedrift}

Praktisk yrkeserfaring er sentralt i yrkesutdanning, men i seg selv ingen garanti for læring. Gjennom veiledning og instruksjon, samtale og systematisk refleksjon utvikler elevene erfaring, språk- og yrkesfaglige begreper i nær samhandling med praksis og gjennom deltakelse i praktisk yrkesutøvelse både i skole og bedrift. Lærerne vi intervjuet, fremhever betydningen av å jobbe med virkelige arbeidsoppdrag $\mathrm{i}$ alle skolefagene som et motiverende grunnlag for å utvikle elevenes yrkesteoretiske kunnskap og kompetanse. «Hvis de skal tegne noe, så er det noe de skal bygge etterpå. Skal elevene utvikle forståelse til annen teori, for eksempel lære å lese tabeller i styrkegrad og dimensjoneringer, så er dette i forhold til den reelle jobben som skal gjøres» (Lærer, BA). I elevundersøkelsen fremhever elevene at det aller beste med skoleåret var å få jobbe praktisk i bedrifter og med relevante arbeidsoppgaver på skolen som integrerer både fellesfag og felles programfag (Hansen \& Haaland, 2015b).

Et grunnleggende prinsipp i fag- og yrkesopplæring handler om nødvendigheten av å lære gjennom eksempler og deltakelse i konkrete praksissituasjoner som elevene er følelsesmessig involvert i og ser hensikten og nytten med (Hiim, 2013; Lave og Wenger, 1991). Bedriften som læringsarena har andre rammevilkår enn skolen. Lærere vi intervjuet, fremhevet betydningen av «å gi elevene tid til refleksjon, til prøving og feiling», som en vesentlig del av læringsprosessen på skolen, og som en del av for- og etterarbeidet etter elevenes bedriftspraksis (Lærer BA) (Hansen \& Haaland, 2015b). Lærerne understreket betydningen av at all læring kan få bruksverdi i nye situasjoner, og en mer allmenn forståelse som viktig og avgjørende for elevenes helhetlige kompetanseutvikling (Illeris, 2012, s. 269). 


\section{Samfunnstjenlig, yrkes-/interessedifferensiert opplæring}

Etter innføring av KL (06) kreves en annen yrkesfaglig og yrkesdidaktisk kompetanse enn tidligere for lærere i yrkesfaglige utdanningsprogram. I tillegg til solid faglig kompetanse innenfor eget fagbrevområde, skal yrkesfaglæreren også ha innsikt i alle (de fleste) yrkene som inngår i de enkelte utdanningsprogram, som grunnlag for å kunne lede og veilede elever i samme klasse med ulike utdanningsplaner. Lærerne på yrkesfag skal kunne begrunne, legge til rette for, lede tilpasset opplæring. De skal drive en meningsfull og yrkesrelevant opplæring for elever med ulike utdanningsplaner og læringsbehov. (Dahlback et al., 2011).

En utfordring i denne sammenheng er ansettelser av yrkesfaglærere, der flere fylkeskommuner foretrekker noen yrkesbakgrunner på Vg1 fremfor andre (Grande, Landro, Lyckander \& Rokkones, 2014). Dette kan ha flere årsaker. I enkelte utdanningsprogram dekker noen yrker flere av kompetansemålene på Vg1 enn andre. Søkere med ingeniørutdanning eller teknisk fagskole prioriteres ved noen skoler foran fagarbeidere med fagbrev og yrkesfaglærerutdanning for stillinger ved Elektrofag (EL), Teknikk- og industriell produksjon (TIP) og Bygg- og anleggsteknikk (BA), mens sykepleiere prioriteres foran fagarbeidere på HO (Dahlback, Hansen, Haaland \& Vagle, 2015). Det har i enkelte utdanningsprogram også vært vanskelig å rekruttere fagfolk inn i lærerjobb i skolen. Mange lærere opplever at teamet de er del av, har smal yrkesfaglig kompetanse, da variert yrkeskompetanse ikke prioriteres ved tilsettinger. Lærere med fag- eller svennebrev og arbeidslivserfaring er en grunnleggende forutsetning for en yrkesdidaktikk preget av fleksibilitet og tidligere yrkesfaglig fordypning slik det foreslås i Meld. St. 20 (2012-2013). Det kan se ut som at avdelinger ved mindre videregående skoler sliter med at de ikke har nok allsidig faglig lærerkompetanse, spesielt i de brede utdanningsprogrammene. I prosjektperioden ble derfor målet om å utvikle et tettere samarbeid mellom skolen og bedrifter innen bygg- og anleggsteknikk sentralt. Spesielt var dette viktig innenfor de bransjene og yrkene der skolens lærere ikke hadde den faglige kompetansen (Hansen \& Haaland, 2015b).

\section{Demokrati og elevenes medbestemmelse}

I spørreunders $\varnothing$ kelsen med elevene, svarte mer enn halvparten av elevene (58\%), at de hadde bestemt seg for yrkesvalg før de var ferdige med ungdomsskolen. Det store flertallet av elevene i Vg1 sier også at de er sikre eller svært sikre (63\%) på yrkesvalget sitt. Disse tallene bekreftes i en studie nylig gjennomført blant 3000 Vg1 og Vg2 elever i fire fylker. (Bødker Lund et al., under publisering) Hvis disse tallene er representative for elever som begynner på 
$\mathrm{Vg} 1$, kan det tolkes som grunnleggende vesentlig for yrkesdidaktikken at innhold og organisering, spesielt i Vg1, er preget av elevenes medvirkning fra første dag. Dette bør selvfølgelig også gjelde for de elevene som enda ikke har bestemt seg for yrkesvalg når de begynner i Vg1 eller Vg2, og som har behov for å prøve ulike yrker de er interessert i for å ta et endelig utdanningsvalg.

Elevenes forventninger til opplæringen har stor betydning for hvordan de opplever skolehverdagen. Det er derfor vesentlig for lærerne å få innsikt i disse forventningene, som grunnlag for planlegging og vurdering av egne tiltak i opplæringen. Alle lærerne vi intervjuet trekker frem en vesentlig faktor som de mener har avgjørende betydning for elevenes motivasjon for læring, og det er at elevene får jobbe med det yrket eller de yrkene de har interesse for eller vil utdanne seg til. Mer enn to tredeler av elevene i unders $\varnothing$ kelsen svarer at det er viktig eller svært viktig for deres motivasjon og engasjement at de får være med og bestemme. «Hvis jeg blir tvunget til å gjøre ting jeg ikke vil holde på med, så er det lite motiverende å fortsette med yrkesfag». «Jeg blir umotivert hvis jeg blir tvunget til å lære noe jeg ikke vil, og kanskje ikke da lære noe i det hele tatt» (Hansen \& Haaland, 2015b). Skaalvik og Skaalvik drøfter motivasjon i forhold til Deci og Ryans fokus på selvbestemmelse, kompetanse og tilhørighet (Deci \& Ryan, 2000) og mener at av disse tre behovene legger Deci og Ryan størst vekt på selvbestemmelse. «Behovet for selvbestemmelse og autonomi handler om et $\emptyset$ nske om å se seg selv som kilde til egne handlinger. Selvbestemt atferd er derfor en atferd som oppleves som frivillig og som kan springe ut fra egen interesse» (Skaalvik \& Skaalvik, 2013, s.145). Forfatterne viser til Gagne og Deci (2005) som hevder at skolen bør legge vekt på det de kaller autonomistøtte. De gir følgende eksempel på hva dette er: 1) Gi elevene hjelp til å finne mening med (og se relevansen av) oppgavene og lærestoffet, 2) gi elevenes mulighet for valg, 3) gi elevene utfordringer, 4) gi elevene feedback. (Skaalvik et. al. 2013. s 149). Yrkesutdanning kan preges av elevmedvirkning på en måte som gjør at elevene har reell innflytelse på det som betyr noe for deres indre motivasjon i skolehverdagen (Hansen og Haaland, 2012; St.meld. nr. 30, (2003-2004), 2004). Med indre motivasjon menes her en handling som er fri for press, fullt ut selvbestemt og kompetansegivende. Viktig aspekt i denne definisjonen er at elevene er oppriktig interessert i det de holder på med og at aktiviteten er tilfredsstillende i seg selv (Illeris, 1999; Lillemyr, 2007). 


\section{Oppsummering - Det er behov for en ny yrkesdidaktikk}

Min motivasjon for å skrive denne artikkelen er å starte en diskusjon blant ulike aktører innen det yrkespedagogiske kunnskapsfeltet, basert på våre funn som klart viser behov for en endring av innholdet og arbeidsmåtene i de yrkesfaglige utdanningsprogrammene og dermed innholdet i begrepet yrkesdidaktikk i skolen. Avslutningsvis vil jeg derfor oppsummere hvilke prinsipper dagens yrkesdidaktikkbegrep bør inneholde, basert på studien som ligger til grunn for innholdet i denne artikkelen:

Yrkesdidaktisk opplæring i skole og bedrift bør være:

- Yrkes- og interessedifferensiert - basert på analyse av yrkene elevene utdanner seg til og tilpasset hver enkelt elevs yrkesvalg og læringsbehov

- Basert på praktiske yrkesoppgaver som er relevante for elevenes utdannings- og yrkesplaner og for opplæring i og integrering av alle skolefag

- Praksisbasert - i samarbeid mellom skole og bedrift, for utvikling av ferdigheter, forståelse og yrkesrelevant kompetanse

- Samfunnstjenlig og yrkesforankret - oppdatert i forhold til dagens og fremtidens kompetansebehov i det enkelte yrket

- Demokratisk og preges av elevenes medbestemmelse - for å sikre elevenes opplevelse av mening og yrkesrelevans, basert på et dialektisk forhold mellom elev og lærer og deres innflytelse på hverandres rolle i opplæringen

Prinsippene over er nødvendig for å oppnå tilpasset opplæring, yrkesrelevans og elevenes opplevelse av mening i yrkesopplæringen. De bør derfor også ligge til grunn for utvikling av lærerkompetanse for å håndtere de store utfordringene i dagens yrkesopplæring i skole og bør få konsekvenser for innhold og arbeidsmåter i yrkesfaglærerutdanningene? Dersom dagens elever skal lære ulike yrker i skolen, begynnende yrkesstolthet og yrkesetisk adferd, forutsetter dette at lærerne har kunnskap om yrkene i eget utdanningsprogram og solid yrkesfaglig og yrkesdidaktisk kompetanse som gjør at de kan:

- analysere yrker og yrkesfaglige arbeidsprosesser - for å basere innhold og arbeidsmåter i Vg1 og brede Vg2 på det yrkene elevene skal utdanne seg til har til felles

- lede yrkes- og interessedifferensiert opplæring

- $\quad$ veilede elevene i forhold til deres konkrete yrkesvalg 
- kartlegge og ta hensyn til elevenes læringsbehov, gjøre beslutninger sammen med dem og lede opplæring preget av elevmedvirkning og elevinnflytelse

- Utvikle et nettverksamarbeid med bedrifter, offentlige virksomheter og andre skoler

Yrkesutdanningens fremtid i videregående skole, går en usikker tid i møte. Yrkesdidaktikken i skolen bør fortsatt preges av en yrkesfaglig læringstradisjon hvor både elevenes, bransjenes og samfunnets behov for kompetanse er i fokus. Da mine frisørelever startet i videregående skole på begynnelsen av 1980-tallet, hadde de bestemt seg for et og samme yrkesvalg i motsetning til dagens elever i Vg1 og brede Vg2. Omtrent seksti prosent av dagens elever har bestemt seg for hvilket yrke de vil utdanne seg til når de begynner ved et yrkesfaglig utdanningsprogram, men yrket de har bestemt seg for er ikke det samme. Det gjør kompetansebehovet for lærere annerledes enn det var for meg. Yrkesdidaktikken skal nå som da bidra til at elevene utvikler relevant og samfunnstjenlig kompetanse i yrkene de har valgt, men opplæringen må være helt annerledes enn den var da fordi elevgruppen i de brede Vg1 og Vg2 er helt annerledes.

Avslutningsvis gjør jeg et forsøk på å videreutvikle definisjonen av begrepet yrkesdidaktikk som er bedre tilpasset dagens yrkesdidaktiske utfordringer i brede utdanningsprogram i Vg1 og Vg2 i skole etter KL (06), basert på funnene i denne studien.

\section{Yrkesdidaktikk i framtidens yrkesopplæring kan defineres som:}

Planlegging, gjennomføring, vurdering og dokumentasjon med begrunnelser og kritisk analyse av praksisbasert, yrkesdifferensiert og yrkesspesifikk opplaring integrert med alle skolefagene, i nart samarbeid mellom skoler og andre virksomheter. Utdanningen er forankret i den enkelte elevs laringsbehov og yrkeslivets og samfunnets dagsaktuelle og fremtidige behov for kompetanse. 


\section{Litteraturliste:}

Andersen, K. (2003). Innføring i mesterlare, yrkesdidaktikk og veiledning. Kristiansand S: HøyskoleForlaget.

Bødtker-Lund, D., Hansen, K. H., Haaland, G. \& Vagle, I. (Under utgivelse). Hvordan fungerer Vg1 - yrkesfaglig utdanningsprogram for elever med ulike utdanningsplaner?. Scandinavian Journal of Vocations in Development.

Dahlback, J, Hansen, K, Haaland, G. \& Sylte, A. L. (2011). Yrkesdidaktisk kunnskapsutvikling og implementering av nye lareplaner - Veien til yrkesrelevant opplaring fra første dag $i \mathrm{Vg} 1$, Oslo: Høgskolen i Akershus.

Dahlback, J. Hansen, K., Haaland, G. \& Rokkones, K. (2014). Yrkesdidaktikk for motivasjon og yrkesrelevans. I Høihilder, E. K \& Lingås, L. G. (red.), Pedagogikk 8. - 13. trinn: profesjonsutdanning av laerere. (s. 339-354) Oslo: Gyldendal Akademisk.

Dahlback, J. Hansen, K. Haaland, G. \& Vagle, I., (2015). Yrkesfaglærerens kompetanse i framtidens skole. I Hansen, Hoel og Haaland (red.), Tett på yrkesopplaring. (s.89108). Fagbokforlaget: Bergen.

Deci, E. L. \& Ryan R. M. (2000). The 'what' and 'why' of goal pursuits: Human needs and the self-determination of behavior. Psychological Inquery, 11, 227 - 268.

Deichman-Sørensen, T., Olsen, O. J., Skånholt, A. \& Tønder, A. H. (2012). Om bredde og fordypning $i$ bygg- og anleggsfagene. Utredning av mulighet for fagkonsentrasjon på Vgl Bygg- og anleggsteknikk. Fafo-rapport 2012:36. Oslo: Fafo.

Gagnè, M. \& Deci, E. L. (2005). Self-determination theory and work motivation. Journal of Organizational Behavior, 26, 331-362.

Grande, S. Ø., Landro, J., Lyckander, R. \& Rokkones, K. (2014). Fram i lyset! En kartlegging av status og behov for laererutdanning for yrkesfag. Oslo: Høgskolen i Oslo og Akershus.

Haga, T. (1994). Yrkesfaglareren i utforming. Utdanning, oppgaver, yrkesinteresser. Bergen: Universitetet i Bergen. AHS gruppe for flerfaglig arbeidslivsforskning. Serie B. Nr.5.

Hansen, K. \& Haaland, G. (2012). Demokratisk klasseledelse i yrkesfag. I. G. Engvik, T. A. Hestbek, T. L. Hoel \& M. B. Postholm (red), Klasseledelse - for elevenes laring (s.6784). Trondheim: Akademika forlag.

Hansen, K. \& Haaland, G. (2015a). Utfordringer i norsk yrkesopplæring. I K. Hansen, T. L. Hoel \& G. Haaland (red): Tett på yrkesopplaring (s.19-46). Bergen: Fagbokforlaget.

Hansen, K. \& Haaland, G. (2015b). Engasjerte og interesserte elever gjennom en meningsfull, helhetlig og relevant yrkesopplæring. I K. Hansen, T. L. Hoel \& G. Haaland (red): Tett på yrkesopplaering. (s. 157-177). Bergen: Fagbokforlaget. 
Hiim, H. \& Hippe, E. (1999). Hva er yrkesdidaktikk? Om sammenhengen mellom yrkes- og profesjonsdidaktikk, yrkeskunnskap og yrkesrelevant forskning. Norsk pedagogisk tidsskrift (s. 177- 183). 3/1999.

Hiim, H. (2013). Praksisbasert yrkesutdanning - Hvordan utvikle relevant yrkesutdanning for elever og arbeidsliv? Oslo: Gyldendal Akademisk.

Haaland, G. (2010). Fagdidaktikk eller yrkesdidaktikk? (Diskusjonsinnlegg ved utvikling av Master i yrkesdidaktikk ved NTNU av 23.03.2010). Trondheim: NTNU.

Illeris, K. (1999). Laring- aktuell laringsteori i spaedninsfeltet mellom Piaget, Freud og Marx. Roskilde: Roskilde Universitets Forlag.

Illeris, K. (2012). Laring. Oslo: Gyldendal Akademisk.

NOU 1996:22. (1996). Larerutdanning. Mellom krav og ideal. Oslo: Kirke-, utdannings- og forskningsdepartementet

NOU 2015:8 (2015). Fremtidens skole. Fornyelser av fag og kompetanser. Oslo: Kunnskapsdepartementet.

Kvale, S. (1993). En pædagogisk rehabilitering av mesterlæren? Dansk paedagogisk tidsskrift $n r .1 .1993$.

Kvale, S. \& Brinkmann, S. (2017). Det kvalitative forskningsintervju. Oslo: Gyldendal Akademisk.

Lave, J. \& Wenger, E. (1991): Situated learning- Legitimate peripheral participation. New York: Cambridge University Press.

Lillemyr, O. F (2007). Motivasjon og selvforståelse, Oslo: Universitetsforlaget

Meld. St. 18 (2012 - 2013). (2013). Lange linjer - kunnskap gir muligheter. Oslo: Kunnskapsdepartementet.

Meld. St. 20 (2012-2013). (2013). På rett vei - Kvalitet og mangfold i fellesskolen, Oslo: Kunnskapsdepartementet.

Nielsen, K. \& Kvale, S. (1999). Mesterlære som aktuell læringsform. I K. Nielsen \& S. Kvale, (red): I Mesterlare. Laring som sosial praksis. (s.17- 34). Ad Notam Gyldendal: Oslo.

Nilsson, L. (2000). Den glömda arbetsuppgiften. I DS: Departementsserien Samverkan mellan skola och arbetsliv: om möjligheterna med lärande i arbete. (S.227 - 264). Stocholm: Fritzez.

Nyen, T. \& Tønder, A. H. (2012). Fleksibilitet eller faglighet? En studie av innføring av prosjekt til fordypning $i$ Kunnskapsløftet. Fafo- rapport 2012:47. Oslo: Fafo.

Opplæringslova. (1998). Lov om grunnskolen og den vidaregåande opplæringa. Hentet fra http://www.lovdata.no/all/nl-19980717-061.html 
Postholm, M. B. (2005). Kvalitativ metode: en innfфring med fokus på fenomenologisk, etnografisk og kasusstudier. Oslo: Universitetsforlaget.

Sannerud, A. R. (2005). Laring på byggeplassen - utopi eller realitet? Et aksjonsforskningsprosjekt i byggebransjen (Doktorgradsavhandling). Program for livslang læring, Roskilde Universitetscenter, Roskilde.

Sennet, R. (2009). Håndvarkeren. Arbejdets kulturhistorie: Hånd og ånd. Viborg: Hoveland.

Skaalvik, E. M. \& Skaalvik, S. (2013). Skolen som laeringsarena: Selvoppfatning, motivasjon og laring. Oslo: Universitetsforlaget.

St.meld. nr. 30 (2003 - 2004). (2003). Kultur for laering. Oslo: Utdannings- og forskningsdepartementet.

Strauss, A. L. \& Corbin, J. M. (1998). Basics of qualitative research: techniques and procedures for developing grounded theory. Thousand Oaks, Calif.: Saage.

Sund, G. H. (2005). Forskjellighet og mangfold-muligheter eller begrensninger for individ og arbeidsplass. Et aksjonsforskningsprosjekt med studier av laring i daglig arbeid, gjennom medvirkning, demokratiske prosesser og interessedifferensiering (Doktorgradsavhandling). Program for livslang læring, Roskilde Universitetscenter, Roskilde.

Utdanningsdirektoratet (2016a). Gjennomgang av det yrkesfaglige utdanningstilbudet. Hentet 20. Februar 2017 fra https://www.udir.no/globalassets/filer/fag-ogyrkesopplering/gjennomgang-av-det-yrkesfaglige-utdanningstilbudet.pdf

Utdanningsdirektoratet (2016b). Forskrift om yrkesfaglig fordypning. Hentet 26. februar 2017 fra https://www.udir.no/laring-og-trivsel/lareplanverket/finn-lareplan/yrkesfagligfordypning/

Utdanningsdirektoratet (2015). Rammeverk for fyr-prosjektet. Hentet 10. mars 2017 fra https://www.udir.no/globalassets/upload/fyr/rammeverk-fyr.pdf

Utdanningsdirektoratet (2006). Prinsipper for opplaringa. Hentet 10. mars 2017 fra http://www.udir.no/Lareplaner/Kunnskapsloftet/Prinsipp-for-opplaringa/

Utvær, B. K. (2013). Staying in or dropping out? A Study of Factors and Critical Incidents of Importance for Health and Social Care Students in Upper Secondary School in Norway. (Doctoral thesis). Program for Lærerutdanning, NTNU, Trondheim.

Young, M. (2004). Conceptualizing vocational knowledge. Some theoretical considerations. In H. Rainbird, A Fuller \& Munro (Eds), Workplace learning in context (pp. 186-200). London: Routledge.

Aarkrog, V. \& Bang, S. W. (2013). Resultater af evalueringer af Kunnskapslфftet: En syntese. Aarhus: Aarhus Universitet. 